Review

\title{
CHARACTERISATION OF LATVIA FRUIT CROP GENETIC RESOURCES BY APPLICATION OF MOLECULAR GENETICS METHODS
}

\author{
Gunārs Lācis \\ Latvia State Institute of Fruit-Growing, Graudu iela 1, Dobele LV 3701, LATVIA; \\ gunars.lacis@Ivai.lv
}

Communicated by Isaak Rashal

\begin{abstract}
A large diversity of fruit crop accessions is maintained at the Latvia State Institute of FruitGrowing, which consists of modern cultivars, landraces and selections from local breeding programmes, as well as germplasm that has resulted from scientific exchange and co-operation with other institutes. Presently, the germplasm collection comprises 2509 accessions of 17 fruit crops; 676 accessions are designated as national genetic resources. Conservation of germplasm itself has little value without characterisation and further utilisation of the stored plant material. To intensify these activities, DNA-based technologies have been implemented in the characterisation of germplasm. Two main groups of molecular markers have been utilised: non-specific markers and gene-specific (functional) markers, subsequently applicable for Marker Assisted Selection (MAS). Genotyping protocols based on SSR, RAPD and Methylation-sensitive amplification polymorphism (MSAP) markers have been developed for twelve fruit crops for use in plant material identification, True-to-Type verification and evaluation of genetic diversity and internal collection structure. In total, 790 accessions have been genotyped using any of the mentioned markers. These markers have been harmonised with the European cooperative programme for plant genetic resources working group (ECPGR WG) recommended sets to ensure international data exchange. Gene specific molecular markers have been applied to apple and pear (resistance to scab), strawberry (resistance to Gnomonia fragariae), sweet cherries and plums (self-incompatibility).
\end{abstract}

Key words: germplasm, molecular markers, MAS, resistance, self-incompatibility, breeding.

\section{INTRODUCTION}

Plant genetic resources (PGR) are the basis of food security, and are an important component of agrobiodiversity and national heritage. They include a diverse range of plant material including landraces, modern cultivars, crop wild relatives and other wild species. Genetic diversity existing in the PGR collections can provide farmers, plant breeders and researchers with possibilities to develop new and more productive crops, preferably resistant to various pests and diseases and adapted to changing environments. PGR activities include collection, conservation, evaluation and characterisation of germplasm and use in breeding and research, which are interdependent components and should be performed jointly in order to ensure efficient and sustainable PGR conservation. An important and critical phase for all PGR activities is evaluation and characterisation, since this will determine the success of germplasm acquisition, maintenance and utilisation efforts. Knowledge about the amount, extent and distribution of genetic variation is the key for developing effective maintenance and management strategies of PGR. It is particularly important for fruit crop genetic resources, which are usually preserved in field collections with safety duplications for each accession. Maintaining duplicated germplasm increases the costs related to the preservation and decrease of collection value (Frankel and Soulé, 1981; Trajkovski and Hjalmarsson, 2007). The level of germplasm characterisation can influence the effective use of PGR in breeding, since breeders are usually looking for well-evaluated plant material containing desirable agricultural traits (e.g. disease resistance, winterhardiness, specific tree or fruit traits etc.).

\section{FRUIT CROP GENETIC RESOURCES IN LATVIA}

The first PGR activities in Latvia started in 1993, when a network of genetic resources collections was established (Rashal and Rashal, 1996). This network included the Dobele Horticultural Plant Breeding Experimental Station (now Latvia State Institute of Fruit-Growing, LSIFG) and Pūre Horticultural Research Station (now Pūre Horticultural Research Centre, Pūre HRC), where a high diversity of fruit crops has been collected and maintained (Rashal and 
Rashal, 1996; Rashal and Lācis, 1999; Ikase et al., 2001). Within this framework, an inventory of collections was performed, and a database of all fruit crop germplasm available in Latvia was established. Work on documentation was started by entering accession passport data. Since the beginning of state support for PGR maintenance, the collection at the LSIFG was defined as the main collection of fruit crop genetic resources (FCGR), and the collection at the Pūre $\mathrm{HRC}$ as the safety duplication. Later, a privately owned collection of V. Vēsminšs was added, which included sweet cherry and grape genetic resources. FCGR activities in Latvia include: collection, preservation, research and utilisation of FCGR.

According to the current PGR policy, advanced foreign germplasm was not included in the national FCGR, and remained in the working collections of institutes and was used in breeding and research. FCGR accessions are divided into two groups:

Group 1 includes cultivars bred in Latvia, as well as clones and elite hybrids originated and selected in Latvia with valuable quantitative or qualitative traits; landraces, and foreign cultivars with a long growing history in Latvia (over 100 years);

Group 2 includes clones and elite hybrids originated in Latvia with valuable quantitative or qualitative traits, which are still in the process of evaluation.

Presently, the collection at the LSIFG comprises of 2509 accessions of 17 crops, including 676 National FCGR accessions (Table 1).

Conservation of germplasm itself has a limited value without evaluation and characterisation as well as further utilisation of the stored plant material. Accurate identification of plant material FCGR collections has high importance in maintenance activities. During the process of collection development there is often a considerable accumulation of documentation errors, false identification of collected germplasm, duplication or loss of accessions during collection renewal. Such errors could have a significant impact on conservation efforts and are impossible to detect without detailed characterisation data (Engels and Visser, 2003). Breeding and research are the main areas of FCGR utilisation and require high levels of evaluation and characterisation to be efficiently utilised in these and further activities. Therefore, evaluation and characterisation of germplasm is an essential task and ideally should be carried out both by phenotypical and molecular marker based genetic characterisation.

The first FCGR characterisation and evaluation activities based on phenotypical traits for fruit crops in Latvia were performed thanks to international co-operation projects. During long-term collaboration with the Department of Horticultural Plant Breeding, Swedish University of Agriculture (SLU-Balsgård) (now Horticultural Plant Breeding Research - Balsgård, Department of Plant Breeding and
Table 1

FRUIT CROP GENETIC RESOURCES AT THE LATVIA STATE INSTITUTE OF FRUIT-GROWING

\begin{tabular}{lcc|c}
\hline \multicolumn{1}{c|}{ Crop } & $\begin{array}{c}\text { Number of } \\
\text { accessions }\end{array}$ & $\begin{array}{c}\text { Number of } \\
\text { national GR } \\
\text { accessions }\end{array}$ & $\begin{array}{c}\text { Number of } \\
\text { genotyped } \\
\text { accessions }\end{array}$ \\
\hline Apple & 1061 & 283 & 157 \\
Pears & 405 & 101 & 40 \\
Plums: domestic & 151 & 45 & 108 \\
\multicolumn{1}{c}{ diploid } & 152 & 25 & 11 \\
Cherries: sweet & 170 & 40 & 170 \\
Black currants & 62 & 33 & 50 \\
Red and white currants & 144 & 38 & 118 \\
Gooseberries & 30 & 16 & 8 \\
Raspberries & 109 & 23 & 26 \\
Sea buckthorn & 71 & 11 & 43 \\
Strawberries & 36 & - & 36 \\
Apricots & 13 & 2 & - \\
Peaches & 35 & 35 & - \\
Grapes & 2 & 2 & - \\
Japanese quince & 26 & 14 & \\
Honeysuckle & 40 & 676 & - \\
Total: & 2509 & 2 & - \\
\hline
\end{tabular}

* Strawberry accessions from Pūre HRC collection have been included in the characterization

Biotechnology, Swedish University of Agricultural Sciences), locally adapted descriptor lists were elaborated and evaluation and characterisation of Latvian and Swedish genetic resources were performed for sweet cherries (Lacis et al., 2009), sour cherries (Lacis et al., 2010), plums (Kaufmane et al., 2002; Kaufmane et al., 2003; Kaufmane et al., 2006), apples (Ikase et al., 2001) and black currants. Collection-wide evaluation and characterisation of FCGR was carried out mainly for the Group 1 PGR plant material. In addition, phenotypic evaluation and characterisation within the framework of several other research projects was carried out for Japanese quince (Chaenomeles japonica (Thunb.) Lindl.) (Ruisa and Lacis, 2001), sweet cherries (Lacis, 2001; Lacis and Rashal, 2000; 2001) and Ribes GR (Strautina and Kampuss, 2002; Kampuss et al., 2007; Karhu et al., 2007). Since 2006, the Latvian Ministry of Agriculture has initiated targeted support for elaboration of descriptor lists as well as evaluation and characterisation of germplasm. In 2007-2009, the Programme on Conservation and Sustainable use of Plants for Food and Agriculture, and Animal, Forest and Fish Genetic Resources was implemented and an additional ten descriptor lists have been developed. Presently, 14 descriptor lists for 16 fruit crops have been developed (Anonymous, 2012) and 179 accessions have been characterised.

\section{APPLICATION OF MOLECULAR MARKERS FOR PGR CHARACTERISATION}

The evaluation and characterisation of PGR collections requires fast, reliable, cost effective and objective methods to 
identify and describe germplasm. Unfortunately, even using a high number of detailed phenotypical descriptors, it is difficult to describe accessions due to environmental influence, growing conditions, plant developmental stage, etc. Therefore, different molecular marker technologies have been implemented in the characterisation of germplasm to obtain accession-specific fingerprints (Weising et al., 2005). Implementation of DNA based genotyping can be used in all steps of PGR activities (e.g. Haussmann et al., 2004; Spooner et al., 2005; Mondini et al., 2009; van Treuren et al., 2010; Börner et al., 2012):

- plant material acquisition (gap analysis and improving composition and coverage of collections, improving sampling strategies);

- maintenance (measuring and reducing genetic drift, monitoring of contamination, detection of duplication, control of regeneration quality, definition of regeneration priorities);

- characterisation (fingerprinting and further diversity studies);

- utilisation (creation of core collections, allele mining basis for Marker Assisted Selection, MAS).

\section{MOLECULAR MARKERS USED IN FCGR CHARAC- TERISATION}

Application of DNA based fingerprinting methods is very important for fruit crops, because they allow to overcome the necessity for long and expensive field evaluations necessary to obtain satisfactory phenotypical data for accession identification. This reduces the investment required for the assessment of a PGR (Laurentin, 2009). Molecular markers have the following advantages: (1) no environmental influence, (2) potentially unlimited and (3) objective measure of variation. In general, two main groups of molecular markers are used for FCGR characterisation:

- non-specific molecular markers, which are not linked to a particular trait and usually are applied for identification of genetic diversity, evaluation of relatedness of available plant material, detection of the structure of genetic resource collections;

- trait specific (functional) markers, subsequently applicable in MAS which are linked to agronomically important traits as well as resistance to various pathogens.

\section{Non-specific molecular markers for FCGR characterisa-} tion. Non-specific molecular markers were among the first utilised for the characterisation of PGR - mostly for evaluation of genetic diversity in collections, accession identification, search for duplicates, and parentage clarification. In the areas of PGR maintenance as well as evaluation and characterisation they have already become routine applications and an integral part of these activities. Currently there is a huge diversity of non-specific molecular markers meth- ods that can be used to characterise PGR (Kumar et al., 2009), therefore, criteria for the selection of the best methods are required. The properties of an ideal molecular marker are: (1) highly polymorphic; (2) co-dominant; (3) frequent occurrence in genome; (4) selective neutral behaviour; (5) easy, fast and cheap detection; (6) easy and fast assay; (7) high reproducibility, and (8) easy exchange of results among laboratories. Unfortunately, it is impossible to find a molecular marker technique that combines all the above properties. Therefore, the advantages and disadvantages of different markers are subject to wide discussions (e.g. Martínez-Gómez et al., 2005; Kumar et al., 2009). Usually the most appropriate marker technique is selected on the basis of the research object and aim of the study, as well as available resources (Kumar et al., 2009). The most commonly used molecular markers for characterisation of PGR include: Restriction Fragment Length Polymorphism (RFLP) (e.g. Panda et al., 2003), Amplified Fragment Length Polymorphism (AFLP) (e.g. Bao et al., 2008), Simple Sequence Repeats (SSR or microsatellites) (e.g. Antonius et al., 2012; Fernandez i Marti et al., 2012; Gross et al., 2012; Potts et al., 2012; Storti et al., 2012), Inter-Simple Sequence Repeats (ISSR) (e.g. He et al., 2011), Random Amplified Polymorphic DNA (RAPD) (e.g. Lisek et al., 2006; Mitre et al., 2009); and Single-Nucleotide Polymorphism (SNP) (e.g. Myles et al., 2010; Fernandez i Marti et al., 2012). For more specific applications, molecular marker techniques, such as Methylation-Sensitive Amplified Polymorphism (MSAP), can be used to detect changes in the level of methylation to evaluate somaclonal variation in plants during propagation (Liet et al., 2008), in order to minimise the possibility of changes occurring through mutation, selection, random drift or contamination.

FCGR screening at the LSIFG has been performed using several types of non-specific molecular markers: SSR, RAPD and MSAP (Table 2). The choice of particular marker type was dependent on the level of particular crop characterisation as well as the aim of the investigation. For well characterised fruit crops (FC) like apple, cherries, strawberries, mainly SSR markers have been used for genotyping, since they have significant advantages (Sefc et al., 2001). RAPD markers, which do not require prior sequence information, were used to genotype crops with limited sequence information (e.g. sea buckthorn) or genotyping of functionally phenotyped germplasm, e.g. mapping of disease resistance in strawberries. In particular studies (apples and pears) MSAP markers have been applied to evaluate stability of plant material during vegetative and in vitro propagation.

Trait specific molecular markers. Although non-specific markers have been widely applied by many users, they are not associated with genes and do not provide functional information about the germplasm. For the efficient use of genetic resources in breeding and research it is important to know what genes are available, and it is important to identify appropriate genes to increase the value of the available germplasm. Application of molecular markers linked to par- 
APPLICATION OF MOLECULAR MARKERS IN THE CHARACTERISATION OF FRUIT CROP GENETIC RESOURCES AT THE LATVIA STATE INSTITUTE OF FRUIT-GROWING

\begin{tabular}{|c|c|c|}
\hline \multirow[t]{2}{*}{ Crop } & \multicolumn{2}{|r|}{ Implemented marker type } \\
\hline & non-specific* & specific \\
\hline Apple & SSR, MSAP & $\begin{array}{l}\text { Scab resistance gene markers: } \\
\text { Vd(Rvi13), Vh2(Rvi2), Vh4(Rvi4), } \\
\text { Vr2(Rvi15), Vbj(Rvi11), Vf/Vjh(Rvi6), } \\
\text { Vb(Rvi12), Vm(Rvi5), } \\
\text { Disease Resistance Gene Analogs mark- } \\
\text { ers }\end{array}$ \\
\hline Pears & SSR, MSAP & $\begin{array}{l}\text { Disease Resistance Gene Analogs mark- } \\
\text { ers }\end{array}$ \\
\hline Plums: domestic & SSR & Self-incomatibility gene $(S f)$ markers \\
\hline diploid & SSR & Self-incomatibility gene (Sf) markers \\
\hline Cherries: sweet & SSR & Self-incomatibility gene $(S f)$ markers \\
\hline sour & SSR & - \\
\hline Black currants & SSR & - \\
\hline $\begin{array}{l}\text { Red and white } \\
\text { currants }\end{array}$ & SSR & - \\
\hline Gooseberries & SSR & - \\
\hline Raspberries & SSR & - \\
\hline Sea buckthorn & SSR, RAPD & - \\
\hline Strawberries & SSR, RAPD & $\begin{array}{l}\text { Disease Resistance Gene Analogs mark- } \\
\text { ers }\end{array}$ \\
\hline
\end{tabular}

* SSR, Simple Sequence Repeats; MSAP, Methylation-sensitive amplification polymorphism; RAPD, random amplification of polymorphic DNA

ticular traits could also facilitate the use of particular germplasm in breeding, especially utilising MAS (Spooner et al., 2005; Ferreira, 2006). Different types of functional markers can be used depending on the purpose of the study, the traits under consideration and the current level of genetic research in a particular fruit crop species. The most common types of markers are:

- molecular markers specific to the particular gene or allele, e.g. traits with monogenic inheritance like self-incompatibility (Sf) (Sonneveld et al., 2003) or disease resistance genes conferring gene-for-gene resistance (Bus et al., 2011);

- consensus molecular markers, which are specific to a consensus sequence of nucleotides that is always present in a large set of independently determined sequences, e.g. consensus markers spanning introns of $S$-RNase and F-Box genes responsible for the self-incompatibility response (Tao and Iezzoni, 2010) or resistance gene analogues (RGA).

\section{IMPLEMENTATION OF MOLECULAR MARKERS IN THE CHARACTERISATION OF LATVIAN FCGR}

Implementation of molecular markers in evaluation and characterisation of FCGR at the LSIFG was started in 1996 in cooperation with the Laboratory of Plant Genetics, Institute of Biology, University of Latvia (LUBI). Collaboration with Prof. A. F. Iezzoni at the Department of Horticulture, Michigan State University (USA) was initiated in 1998, which resulted in the implementation of molecular markers in the characterisation of cherry genetic resources (GR) (e.g. Lacis et al., 2008; Lacis et al., 2009; Lacis, 2010; Lacis et al., 2010; Lacis et al., 2011). In 2000, collaboration with SLU-Balsgård was started in the framework of the project "Characterisation of the Latvian and Swedish Sweet and Sour Cherry Genetic Resources" (2000-2004), which included characterisation of Latvian and Swedish sweet and sour cherry genetic resources using molecular markers (Lacis, 2010). These activities were performed in the molecular biology laboratories of LUBI, SLU-Balsgård and MSU. An important milestone in the implementation of molecular genetics in characterisation of Latvian FCGR was in 2005, when the Laboratory of Molecular Biology was established at the LSIFG, which developed into the Unit of Genetics and Molecular Biology in 2008. In 2006, the Latvian genetic resources system was reorganised, which resulted in the creation of the Genetic Resource Centre at the Latvian State Forest Research Institute "Silava", which also included a genetic analysis laboratory. This laboratory is equipped with a high throughput genetic analyser, which enabled to increase the number of samples analysed and to implement new marker technologies. Starting in 2006, the Ministry of Agriculture has supported targeted FCGR genotyping. SSR marker methods for apple, cherry, currant, gooseberry, pear, raspberry, plum, sea buckthorn and strawberry have been implemented and 305 accessions have been genotyped. In parallel to the FCGR programme, the LSIFG has implemented a series of research projects, which included genotyping of fruit crops, and application of gene specific markers. This has significantly increased the number of genotyped accessions and in some cases (e.g. cherries, black currants, sea buckthorn, strawberries), the number of genotyped samples is larger than number of particular crop accessions in the national PGR list (Table 1).

Collection-wide genotyping using non-specific markers at the LSIFG has been performed for apples, black, red and white currants, gooseberries, raspberries, sweet and sour cherries, sea buckthorn. The obtained genotypes were used mainly for the identification of genotypes - detection of duplication in the collections and evaluation of genetic diversity and structure within collections.

Genotyping of cherry GR. Sweet cherry was the first fruit crop in Latvia, for which molecular markers have been implemented. Research was started by selection of a limited number of SSR markers to characterise Latvian and Swedish sweet cherry genetic resource collections with the aim of creating a common core collection (Lacis et al., 2009). The applied approach was found to be useful for the preliminary characterisation of sweet cherry germplasm; a set of three highly polymorphic SSR markers was able to discriminate closely related accessions and could therefore be used in the identification of duplicated accessions. Moreover, the number of alleles identified in the Swedish and Latvian collections indicated that these collections represent a potentially 
higher level of diversity than found in germplasm maintained in other countries (Lacis et al., 2009). Later, genotyping of sweet cherry genetic resources was continued and at present 25 SSR markers have been applied, combining the ECPGR Prunus WG recommended marker set (Clarke and Tobutt, 2009) and highly polymorphic markers selected at the LSIFG (PceGA25, PceGA59, PMS 2, PMS 3, PMS 40, PMS 49, PMS 67, PS08E08, PS12A02, UDP96-005, and UDP97-402). Currently 170 sweet cherry accessions have been genotyped and obtained data used in the creation of molecular identity profiles (Table 1). The obtained marker information has been included in the genetic resources data base and can be provided for the international data exchange systems as well as used in breeding programmes for the planning of crosses. Genotyping of local sweet cherries has been performed also by Stanys et al. (2012) using a similar set of SSR markers - ten of 14 applied markers were the same as in our study. High discrimination power of SSR markers and applicability in accession identification was observed in that study, which corresponded with our findings. This study confirmed also the applicability of a low number of highly polymorphic markers (two) in sweet cherry accession discrimination, as observed previously by us (Lacis et al., 2009). Good applicability of this SSR marker set in sweet cherry plant material characterisation has been observed also in wild populations, genotyped by a set of nine markers (Jarni et al., 2012) with a high average number of identified alleles and heterozygocity (7.3 and 0.704 , respectively).

The genotyping of sour cherries has been performed using the same limited marker set as for sweet cherries (PceGA25, PMS3 and PMS49) and fingerprints of Latvian and Swedish sour cherry accessions have been obtained. Further data analysis showed that Baltic (Latvian and Lithuanian) landraces included in the investigation showed close genetic relatedness with Scandinavian landraces (Lācis et al., 2011). This work was continued and in total 26 SSR markers were implemented for sour cherry GR characterisation (Lacis and Kota, 2013). Currently, 50 sour cherry accessions have been genotyped (Table 1). Research on sour cherries showed that the ECPGR Prunus WG marker set (Clarke and Tobutt, 2009) was readily transferable to other Prunus species e.g. tetraploid Prunus cerasus, where correspondence between accession grouping based on SSR data and known pedigree was found, confirming the reliability of the selected markers. The applied marker set ensured the discrimination of closely related clones of local landraces, as well as identification of duplicates in the collection (Lacis and Kota, 2013). The importance of local sour cherry germplasm characterisation, accession identification has been emphasized also by K. Antonius and colleagues (2012a). Application of nine SSR markers allowed discrimination of 52 sour cherry accessions and revealed a high number of alleles (8.0 in average), similar to our findings.

Genotyping of apple GR. The most important fruit crop in Latvia is apple, represented by 283 accessions in the list of National genetic resources (Table 1). Collection-wide screening of apple germplasm was started using eight of the ECPGR Malus/Pyrus WG SSR markers (CH02d08, CH04c07, CH01e12, CH01h01, CH02c09, CH02c06, $\mathrm{CH01f02,} \mathrm{NZ05g8)} \mathrm{recommended} \mathrm{to} \mathrm{characterise} 109$ accessions (Lacis et al., 2011). These SSR markers showed suitability for evaluation of genetic diversity and relatedness of Latvian apple genetic resources and ensured discrimination of all accessions, including varieties sharing the same pedigree. The obtained results also enabled confirmation or prediction of possible parentage of apple cultivars. Seven of these SSR markers were further utilised to genotype an additional 129 apple accessions. Although cluster analysis based on the SSR genotyping data did not reveal a clear pattern with well-defined cultivar groups, it confirmed some relationships based on known or putative pedigrees, as well as suggested the possible parentage of some cultivars (Ikase and Lacis, 2013). A larger number of SSR markers has been used in some other collection-wide apple genotyping attempts (e.g. Potts et al., 2012; Sikorskaite et al., 2012; Storti et al., 2012), confirming applicability of these markers for apple germplasm of different origin as well as suitability for data comparison and harmonisation among laboratories.

In some cases, for apple and pear GR characterization, only molecular marked method adaptation and implementation has been done without further large-scale genotyping. The selected apple and pear accessions ( 8 samples for each crop) were genotyped by MSAP markers to adapt and implement the method and obtain initial fingerprints. Eight pear accessions (AMD 42-5-28, BP 8965, 'Belorusska Pozdnaja', 'Conference', 'Mramornaja', Pyrus ussuriensis, 'Talgarskaja Krasavitsa' and 'Tihij Don') have been selected and used for adaptation and implementation of SSR markers. Experimental results allowed to select ten SSR markers, which were the most suitable for pear germplasm fingerprinting - CH01f02, CH01h10, CH02a08, CH02b12, CH02d11, CH02f06, Py02b1, Py05g8, PyBGT23, PyKA16 (Gianfranceschi et al., 1998; Yamamoto et al., 2002). Similar pear genetic resources fingerprinting has been done in Sweden using a set of ten SSR markers (CH01d08, CH01d09, CH01f07a, CH03d12, CH03g07, CH04e03, CH05c06, EMPc11, EMPc117 and GD147) (Sehic et al., 2012). Considering the good applicability of these markers for Swedish pear genetic resource genotyping, the set of SSR markers previously selected for Latvian pear characterisation should be harmonised.

Genotyping of berry crop GR. International application of molecular markers and comparison of genotypes was supported in the EU project "Core collection of Northern European gene pool of Ribes - RIBESCO” (Karhu et al., 2007), in which 846 Ribes accessions from eight Northern European countries: 400 black currants (Ribes nigrum), 202 red and white currants (Ribes rubrum group), 242 gooseberries (Ribes uva-crispa), and 2 jostaberries (R. nigrum $x R$. uva-crispa) were analysed, among them 257 Ribes accessions from Latvia. The North European Ribes germplasm was characterised by six SSR markers (Antonius et al., 
$2012 b$ ), with the aim of evaluating genetic diversity and to select accessions for the common core collection. Application of selected SSR markers allowed selection of a core collection of Ribes accessions, which represented 64\% of black currant, $80 \%$ of red and white currant and $61 \%$ of gooseberry alleles identified in the region (Antonius et al., 2012b). A similar SSR marker set was used for characterisation of different Ribes species and interspecific hybrids from North Italy and Switzerland (Cavanna et al., 2009). In contrast to our results, the markers RJL-2, RJL-5, RJL-6 and RJL-7 did not show amplification in Ribes germplasm. In the State Research Programme ,Innovative Technologies for fhe Development of High- Value, Safe and Healthy Food Products from Genetically, Physiologically and Biochemically Various Plant and Animal Material" project „High-Value Latvian Berries: from Cultivar to High-Quality, Healthy and Safe Product", an additional 105 black currant accessions were genotyped using 14 SSR markers, including QTLs linked to important traits such as hundred berry weight, dates of bud break, full leaf, first flower and full flower, specific gravity as well as titratable juice acidity, $\mathrm{pH}$ and ascorbic acid concentration. The tested SSR markers showed good applicability in the analysis of complex, interspecific hybrids obtained from several different Ribes species and were able to identify all Ribes accessions maintained in the LSIFG collection (Lācis et al., unpublished data).

A raspberry breeding programme has been implemented at the LSIFG, and thus the evaluation of breeding material and identification of potential donors of necessary traits is a high priority. Fifteen previously described polymorphic SSR primer pairs developed in Rubus ideaeus L. (Graham et al., 2002; Badjakov et al., 2005) were tested on 43 raspberry accessions to adapt a fast and reliable method for screening of raspberry germplasm. Three to 13 alleles were identified for each locus with 6.6 alleles per marker on average (Lācis et al., unpublished data). Latvian raspberry cultivars showed high diversity, which indicated a sufficiently broad genetic base of plant material used in the breeding programme. The use of these markers in conjunction with pedigree information can allow monitoring of the genetic diversity within the Latvian raspberry breeding programme, and can be used in the planning of crosses aimed to broaden their genetic base (Lācis et al., unpublished data). These results showed a lower number of alleles than was previously observed in other investigations on raspberries with a similar number of accessions (Graham et al., 2002). The investigation results were very similar to data published by Badjakov et al. (2005) on 16 Bulgarian raspberry varieties.

Genotyping of sea buckthorn germplasm. Sea buckthorn (Hippophae rhamnoides L.) is becoming a promising crop in Latvia and plant material used both for breeding and growing has a geographically diverse origin and is potentially genetically variable. The evaluation of 36 sea buckthorn accessions grown in Latvia was undertaken using eight SSR (Wang et al., 2008) and 16 RAPD (OPA-02,
OPA-03, OPA-08, OPA-11, OPA-18, OPB-07, OPB-09, OPB-17, OPD-02, OPD-03, OPD-05, OPD-08, OPD-11, OPD-13, OPD-18, OPD-20) markers. The selected sets of SSR and RAPD markers revealed a high level of polymorphism and were applicable to different $H$. rhamnoides subspecies, as well as in crosses among $H$. rhamnoides ssp. mongolica, ssp. rhamnoides and ssp. fluviatilis. The utilised DNA markers will provide an additional tool to sea buckthorn breeders for cultivar identification and assessment of breeding material (Lācis et al., unpublished data).

Application of gene specific molecular markers. An important challenge of PGR activities is utilisation of collected and maintained plant material in research and breeding. Since this depends on the level of germplasm characterisation and identification of valuable features, both groups of specific molecular markers (molecular markers specific to the particular gene or allele and consensus molecular markers, which are specific to a consensus sequence of nucleotides that is always present in a large set of independently determined sequences) have been used at the LSIFG in the characterisation and other research of the FCGR collection.

Sweet cherry ( $P$. avium L.) is a typical out-crossing species with a mono-factorial and multi-allelic gametophytic incompatibility system governed by a single $S$-locus with multiple alleles (de Nettancourt, 1977). Therefore, in sweet cherry orchards as well as for breeding purposes, suitable pollinator cultivars must be used to ensure successful fertilisation and subsequent fruit development. Molecular markers for six of the most common sweet cherry S-alleles were used to genotype 44 accessions in the LSIFG germplasm collection (Lacis et al., 2008). Data of $S$-genotyping was included in a review on sweet cherry self-incompatibility allele identification work in Europe (Schuster, 2012). The $S$-allele information gained from this study is useful in breeding programmes for the planning of crosses, for conservation of alleles and population genetics studies. Genotyping of the self-incompatibility gene $(S f)$ ensured information on $S f$ gene allele distribution and inheritance, which is important in the development of a GR maintenance strategy. The obtained fingerprints are used also as an additional cultivar identification tool and in the detection of self-compatible sweet cherry seedlings in the early stages of the breeding process (Lacis and Kota, 2008).

Scab disease on apple caused by ascomycetous fungi Venturia inaequalis is an economically important disease worldwide (Bus et al., 2011). In this regard, 109 apple accessions nominated as National PGR were analysed using a marker for the scab resistance gene Rvi6 (Vf) (Lacis et al., 2011). One, six and 102 genotypes of VfVf, Vfvf, vfvf were detected, respectively. Venturia inaequalis has demonstrated a high ability to overcome single gene resistance (Bus et al., 2011), and therefore screening of the apple GR collection has been continued using molecular markers associated with other scab resistance genes: Vh2 (Rvi2), Vh4 (Rvi4), Vm (Rvi5), VflVjh (Rvi6), Vbj (Rvil1), Vb (Rvil2), $V d$ (Rvi13), Vr2 (Rvi15) (Patocchi et al., 2009) to find possible resistance sources for breeding and to perform scab re- 
sistance gene diversity analysis in the germplasm (Lācis et al., unpublished data).

\section{Application of gene group specific molecular markers.} Application of gene or allele-specific markers is not possible in less-studied crops or for traits for which such functional markers have not been developed. In this case, markers identifying gene groups or classes can be utilised. Their application can be used to detect novel genes or alleles influencing already well-studied traits, and in research of heredity and the genetic basis of other traits about which limited information is available.

Plums belong to the Rosaceae family have a gametophytic self-incompatibility system (Hegedüs and Halász, 2007). Although extensive studies on self-incompatibility have been done in sweet cherries ( $P$. avium L.), sour cherries, apricots and some diploid plum species, there is a limited number of genetic studies in hexaploid domestic plums $(P$. domestica L.), due to the complex genome of this species and its high ploidity (Hegedüs and Halász, 2007; Tao and Iezzoni, 2010). DNA-based $S$-genotyping was performed on 99 plum accessions (7 diploid and 92 hexaploid plums) to evaluate the genetic diversity of the germplasm collection and to characterise possible $S$-allele composition and occurrence (Kota and Lacis, 2013). The utilised molecular markers had been developed for other Prunus species and had not been used previously for plum $S f$ genotyping. Consensus primers flanking the first and second intron of the $S$-RNase gene and the SFB intron specific primers showed good applicability in plums. An additional six S-locus-specific markers have been used to study the genetics of self-compatibility and to test interspecific transferability of markers and their use in domestic plums. Genotyping of 33 cultivars showed that the applied primer pairs had good transferability among Prunus species and application of these primer pairs allowed discrimination of all plum cultivars in the LSIFG collection by unique S-genotype. According to the obtained results, primer pairs EMPC2consFD/ EM-PC3cons RD, PasPcons-F1/ PaC1cons-R1 and F-Box50A/ F-Box intronR were suggested as supplementary markers in the characterisation and identification of plum germplasm with potential functional application. Although strict segregation of plum cultivars according to compatibility groups (self-compatible, partly self-compatible and self-incompatible) was not observed, group-unique amplification fragments were identified, which could serve as a baseline for further development of specific markers (Kota-Dombrovska and Lācis, 2013).

In most breeding programmes new sources of resistance to diseases are a high priority, especially in cases where genefor-gene resistance is not available or the nature of particular resistance mechanisms are unknown. For this purpose, markers specific to wide resistance-linked gene groups have high utility, e.g. the gene containing the Nucleotide Binding Site - Leucine-Rich Repeat (NBS-LRR) motifs (DeYoung and Innes, 2006). Genes from the NBS-LRR class have been linked with resistance to different pathogens, and their conserved sequences have been already used to isolate re- sistance gene analogues (RGAs) and to design degenerate primers (Bai et al., 2002). These molecular markers have been used at the LSIFG in research on resistance of apple and pear cultivars to apple and pear scab (caused by Venturia pyrina), as well as strawberry resistance to root rot and petiole blight (caused by Gnomonia fragariae) (Morocko et al., 2006). The NBS-LRR protein coding genes were among the resistance-linked markers utilised, since their involvement in scab resistance reaction has been reported previously (Galli et al., 2010). Molecular markers for this group of genes have already been developed and utilised in many plant species, including apple (Mafofo, 2008; Fahrentrapp et al., 2013). In this regard, application of NBS-LRR gene markers in the characterisation of LSIFG PGR collections was started by genotyping of 75 apple cultivars.

Studies on resistance to the pear scab pathogen $V$. pyrina in European pear (P. communis) are at an early stage (Pierantoni et al., 2007). The available knowledge on pear resistance is mostly as a general description of cultivar performance in field conditions and only in few cases have systematic field evaluation results based on wide screening of collections been published (Postman et al., 2005). In further investigation, QRL (Quantitative Resistance Loci) and NBS-LRR molecular markers have been implemented and used in the screening of selected germplasm to reveal potential inheritance mechanisms of resistance and resistance sources. Currently 41 selected accessions of pear have been genotyped using molecular markers specific to QRL and NBS-LRR to analyse the variability in pear germplasm (Lācis et al., unpublished data).

Similarly, NBS-LRR molecular markers in combination with RAPD markers have been applied to investigate strawberry resistance to root rot and petiole blight. 55 strawberry cultivars have been screened for resistance to Gnomonia fragariae and two sets of strawberry cultivars (resistant and susceptible) were selected (Sokolova and MoročkoBičevska, unpublished data). Bulk segregant analysis with application of RAPDs and molecular markers specific to NBS-LRR genes was implemented to evaluate genetic differences between the groups of cultivars and to identify resistance specific fragments for further germplasm evaluation and marker development (Samsone et al., unpublished data). Strawberry cultivars with the highest and lowest resistance assessment were used in creation of a mapping population and about 300 F1 seedlings were obtained for further evaluation of resistance and testing of possible resistance mechanisms to G. fragariae.

\section{CONCLUSIONS}

Implementation of molecular genetic methods significantly increased the level of Latvian fruit crop genetic resources characterisation, ensured successful and optimal maintenance of genetic resources collections, increased dissemination of information about Latvian fruit crop genetic re- 
sources internationally, as well as improved and intensified breeding programmes.

Application of trait specific (e.g. disease resistance, selfcompatibility) molecular markers allowed identifying donors of desirable genes coding these traits, increased the total value of Latvian fruit crop genetic resources nationally and internationally.

\section{ACKNOWLEDGEMENTS}

The article was prepared in the frame of the ERDF project No. 2010/0192/2DP/2.1.1.2.0/10/APIA/VIAA/007, ,, Support for the strengthening of international reputation and competitiveness of Latvian fruit science".

\section{REFERENCES}

Anonymous, (2012, November). Latvijas genētiskie resursi: Deskriptori [Latvian genetic resources: Descriptors]. Retrieved 12 November 2012, from http://www.genres.lv/kulturaugi/deskriptori/

Antonius, K., Aaltonen, M., Uosukainen, M., Hurme, T. (2012a). Genotypic and phenotypic diversity in Finnish cultivated sour cherry (Prunus cerasus L.). Genet. Resour. Crop Evol., 59, 375-388.

Antonius, K., Karhu, S., Kaldmäe, H., Lacis, G., Rugenius, R., Baniulis, D., Sasnauskas, A., Schulte, E., Kuras, A., Korbin, M., Gunnarsson, Å., Werlemark, G., Ryliskis, D., Todam-Andersen, T., Kokk, L., Järve, K. (2012b). Development of the Northern European Ribes core collection based on a microsatellite (SSR) marker diversity analysis. Plant Gen. Res. Cha. Utiliz., 10 (1), 70-73.

Badjakov, I., Todorovska, E., Boicheva, R., Atanassov, I., Atanassov A. (2005). Assessment of genetic diversity in Bulgarian raspberry germplasm collection by microsatelite markers (SSR). Biotechnol. Biotechnol. Eq., 19 (1), 43-47.

Bao, L., Chen, K., Zhang, D., Li, X., Teng, Y. (2008). An assessment of genetic variability and relationships within Asian pears based on AFLP (amplified fragment length polymorphism) markers. Sci. Hort., 116, 374-380.

Börner, A., Khlestkina, E. K., Chebotar, S., Nagel, M., Arif, M. A. R., Neumann, K., Kobiljski, B., Lohwasser, U., Röder, M. S. (2012). Molecular markers in management of ex situ PGR: A case study. J. Biosci., 37, 871-877.

Bus, V. G. M., Rikkerink, E. H. A., Caffier, V., Durel, C.-E., Plummer, K. M. (2011). Revision of the nomenclature of the differential host-pathogen interactions of Venturia inaequalis and Malus. Annu. Rev. Phytopathol., 49, $391-413$

Cavanna, M., Torello Marinoni, D., Beccaro, G. L., Bounous, G. (2009). Microsatellite-based evaluation of Ribes spp. germplasm. Genome, $\mathbf{5 2}$ (10), 839-848.

Clarke, J. B., Tobutt, K. R. (2009). A standard set of accessions, microsatellites and genotypes for harmonizing the fingerprinting of cherry collections for the ECPGR. Acta Hort., 814, 615-618.

de Nettancourt, D. (1977). Incompatibility in angiosperms. Sexual Plant Reprod., 10, 185-199.

DeYoung, B. J., Innes, R. W. (2006). Plant NBS-LRR proteins in pathogen sensing and host defence. Nat. Immunol., 7 (12), 1243-1249.

Engels, J. M. M., Visser, L. (eds). (2003). A Guide to Effective Management of Germplasm Collections. IPGRI Handbooks for Genebanks, No. 6. IPGRI, Rome, Italy. 172 pp.

Fahrentrapp, J., Broggini, G. A. L., Kellerhals, M., Peil, A., Richter, K., Zini, E., Gessler, C. (2013). A candidate gene for fire blight resistance in Malus $\times$ robusta 5 is coding for a CC-NBS-LRR. Tree Genetics Genomes, 9 (1), $237-251$.
Fernandez i Marti, A., Athanson, B., Koepke, T., Font i Forcada, C., Dhingra, A., Oraguzie, N. (2012). Genetic diversity and relatedness of sweet cherry (Prunus avium L.) cultivars based on single nucleotide polymorphic markers. Front. Plant Sci., 3, 116.

Ferreira, M. E. (2006). Molecular analysis of gene banks for sustainable conservation and increased use of crop genetic resources. In: Ruane, J., Sonnino, A. (eds.). The Role of Biotechnology in Exploring and Protecting Agricultural Genetic Resources (pp. 121-127). Rome: FAO.

Frankel, O. H., Soulé, M. E. (1981). Conservation and Evolution. Cambridge, UK: Cambridge University Press, 327 pp.

Galli, P. Patocchi, A., Broggini, G. A. L., Gessler, C. (2010). The Rvi15 (Vr2) Apple scab resistance locus contains three TIR-NBS-LRR Genes. MPMI, 23 (5), 608-617.

Gianfranceschi, L., Seglias, N., Tarchini, R., Komjanc, M., Gessler, C. (1998). Simple sequence repeats for the genetic analysis of apple. Theor. Appl. Genet., 96, 1069-1076.

Graham, J., Smith, K., Woodhead, M., Russell, J. (2002). Development and use of simple sequence repeat SSR markers in Rubus species. Mol. Ecol. Notes, 2 (3), 250-252.

Gross, B. L., Volk, G. M., Richards, C. M., Forsline, P. L., Fazio, G., Chao, C. T. (2012). Identification of „Duplicate” Accessions within the USDA-ARS National Plant Germplasm System Malus Collection. J. Amer. Soc. Hort. Sci., 137 (5), 333-342.

Hattendorf, A., Debener T. (2007). Molecular characterization of NBSLRR-RGAs in the rose genome. Physiol. Plantarum, 129, 775-786.

Haussmann, B. I. G., Parzies, H. K., Presterl, T., Sušić, Z., Miedaner T. (2004). Plant genetic resources in crop improvement. Plant Gen. Res., 2 (1), 3-21.

He, P., Li, L., Li, H., Wang, H., Yang, J., Wang, Y. (2011). Genetic analysis of wild apple resources in Shandong province based on inter-simple sequence repeats (ISSR) and sequence-specific amplification polymorphism (S-SAP) markers. Afr. J. Biotechnol., 10 (46), 9501-9508.

Hegedüs, A., Halász J. (2007). Recent findings of the tree fruit self-incompatibility studies. Int. J. Hort. Sci., 13 (2), 7-15.

Ikase, L., Lacis, G. (2013). Apple breeding and genetic resources in Latvia. Acta Horticulturae, 976, 69-74.

Ikase, L., Trajkovski V. (2001). The Swedish-Latvian Malus genetic resources research program. In: Broad Variation and Precise Characterization - Limitation for the Future. EUCARPIA Section Genetic Resources, 16-20 May 2001 (pp. 38-39). Poznan, Poland.

Ikase, L., Lacis, G., Kaufmane, E. (2001). Fruit crop genetic resources in Latvia. Biologija, 4, 23-25.

Jarni, K., De Cuyper, B., Brus, R. (2012). Genetic variability of wild cherry (Prunus avium L.) seed stands in Slovenia as revealed by nuclear microsatellite loci. PLoS ONE, 7 (7), e41231.

Kampuss, K., Strautina, S., Kampuse S. (2007). Red and white currant genetic resources in Latvia. Acta Hort., 760, 397-403.

Karhu, S., Antonius, K., Kaldmäe, H., Pluta, S., Kimmo, R., Ryliškis, D., Sasnauskas, A., Schulte, E., Strautina, S., Grout B. (2007). The core collection of the Northern European gene pool of Ribes created by RIBESCO Project. Sodininkyste ir Daržininkyste (Horticulture and Vegetable Growing), 26 (3), 179-186.

Kaufmane, E., Ikase, L., Trajkovski, V., Lacis G. (2002). Evaluation and characterization of plum genetic resources in Sweden and Latvia. Acta Hort., 577, 207-213.

Kaufmane, E., Ikase, L., Trajkovski, V. (2003). Evaluation of Swedish plum varieties and hybrids in Sweden and Latvia. Sodininkyste ir Daržininkyste (Horticulture and Vegetable Growing), 22 (1), 62-73.

Kaufmane, E., Lacis, G., Ikase, L. (2006). Current situation of the Latvian Prunus collections - conservation, evaluation and characterization for the 
establishment of core collections. In: Report of a Working Group on Prunus, Biodiversity International, pp. 66-74.

Kota, I., Lacis, G. (2013). Evaluation of genetic diversity in plum germplasm collection using DNA-based $S$-genotyping. Acta Hort., 985, 35-42

Kota-Dombrovska, I., Lācis, G. (2013). Evaluation of domestic plum (Prunus domestica L.) self-incompatibility locus diversity using DNA-based S-genotyping. Proc. Latvian Acad. Sci., Section B., 67 (2).

Kumar, P., Gupta, V. K., Misra, A. K., Modi, D. R., Pandey, B. K. (2009). Potential of Molecular Markers in Plant Biotechnology. Plant Omics J., 2 (4), 141-162.

Lacis, G. (2001). Morphological analysis of Latvian sweet cherry (Prunus avium L.) genetic resources collection. In: Broad Variation and Precise Characterization - Limitation for the Future. EUCARPIA Section Genetic Resources, 16-20 May 2001 (pp. 225-228). Poznan, Poland.

Lacis, G. (2010). Characterisation of the Latvian and Swedish Sweet and Sour Cherry Genetic Resources. Acta Universitatis Agriculturae Sueciae, Doctoral Thesis, No. 2010:89, Sweden. 39 pp.

Lacis, G., Kaufmane, E., Rashal, I., Trajkovski, V., Iezzoni, A. F. (2008). Identification of self-incompatibility $(S)$ alleles in Latvian and Swedish sweet cherry genetic resources collections by PCR based typing. Euphytica, 160, 155-163.

Lacis, G., Kaufmane, E., Trajkovski, V., Rashal, I. (2009). Morphological variability and genetic diversity within Latvian and Swedish sweet cherry collections. Acta Univ. Latv., 753, 19-32.

Lācis, G., Kota, I. (2011). SSR marker-based fingerprinting for sour cherry (Prunus cerasus) genetic resources identification and management. Acta Hort., 976, 251-256.

Lacis, G., Kota, I., Ikase, L., Rungis, D. (2011). Molecular characterization of the Latvian apple (Malus) genetic resource collection based on SSR markers and scab resistance gene $V f$ analysis. Plant Gen. Res. Char. Utiliz., 9 (2), 189-192.

Lacis, G., Rashal, I. (2000). Evaluation of variability of morphological traits of Latvian local sweet cherry (P. avium) accessions by means of multidimensional analysis. In: Proceedings of International Conference "Fruit Production and Fruit Breeding" (pp. 147-151). Polli, Estonia.

Lacis, G., Rashal, I. (2001). Use of multidimensional statistical approaches in charecterization of Latvian sweet cherry (Prunus avium L.) genetic resources. Hort. Veget. Grow., 20 (3), 211-221.

Lacis, G., Rashal, I., Ruisa, S., Trajkovski, V., Iezzoni, A. F. (2009). Assessment of genetic diversity of Latvian and Swedish sweet cherry (Prunus avium L.) genetic resources collections by using SSR (microsatellite) markers. Scientia Hort., 121, 451-457.

Lacis, G., Rashal, I., Trajkovski, V. (2010). Comparative analysis of sweet cherry $(P$. avium) genetic diversity revealed by two methods of SSR marker detection. Proc. Latvian Acad. Sci. Section B, 64 (3/4), 149-158.

Lācis, G., Rashal, I., Trajkovski V. (2011). Implementation of a limited set of SSR markers for screening of genetic variability in Latvian and Swedish sour cherry (Prunus cerasus L.) genetic resources collections. Proc. Latvian Acad. Sci. Section B, 65 (1/2), 21-28.

Lācis, G., Ruisa, S., Kota, I. (2008). Molecular marker application in breeding of self- and cross-compatible sweeet cherry (P.avium L.) varieties. In: Proceedings of International Scientific Conference ,S Sustainable Fruit Growing: From Plant to Product”, 28-31 May 2008 (pp. 158-164). Latvia State Institute of Fruit-Growing, Dobele, Latvia.

Lacis, G., Trajkovski, V., Rashal, I. (2010). Phenotypical variability and genetic diversity within accessions of the Swedish sour cherry (Prunus cerasus L.) genetic resources collection. Biologija, 56 (1/4), 1-8.

Laurentin, H. (2009). Data analysis for molecular characterization of plant genetic resources. Genet. Resour. Crop Evol., 56, 277-292.

Li, X., Xu, M., Korban, S. S. (2002). DNA methylation profiles differ between field- and in vitro-grown leaves of apple. J. Plant Physiol., 159, 1229-1234.
Lisek, A., Korbin, M., Rozpara E. (2006). Using simply generated RAPD markers to distinguish between sweet cherry (Prunus avium L.) cultivars. J. Fruit Ornamen. Plant Res., 14 (1), 53-59.

Mafofo, J. (2008). Saturation sequencing, characterisation and mapping of the NBS-LRR resistance gene family in apple, Malus $x$ domestica (Borkh.). $\mathrm{PhD}$ Thesis, University of the Western Cape. $351 \mathrm{pp}$

Martínez-Gómez, P., Sánchez-Pérez, R., Rubio, M., Dicenta, F., Gradziel, T. M., Sozzi, G. O. (2005). Application of recent biotechnologies to Prunus tree crop genetic improvement. Ciencia e Investigación Agraria, 32 (2), 73-96.

Mitre, I., Lukács, L., Ardelean, M., Mitre, V., Sestras, R., Pop, R., Cordea, M., (2009). Genotypic Variability of the Main Apple Cultivars Grown in Transylvania, Romania, Evaluated by Means of RAPD Analysis. Not. Bot. Hort. Agrobot. Cluj, 37 (1), 261-264.

Mondini L., Noorani A., Pagnotta M. A. (2009). Assessing plant genetic diversity by molecular tools. Diversity, 1, 19-35.

Morocko, I., Fatehi, J., Gerhardson, B. (2006). Gnomonia fragariae, a cause of strawberry root rot and petiole blight. Eur. J. Plant Pathol., 114 (3), 235-244.

Myles, S., Chia, J.-M., Hurwitz, B., Simon, C., Zhong, G.Y., Buckler, E., Ware, D. (2010). Rapid genomic characterization of the genus Vitis. PLoS ONE, 5 (1): e8219.

Panda, S., Martín, J. P., Aguinagalde, I. (2003). Chloroplast DNA study in sweet cherry cultivars (Prunus avium L.) using PCR-RFLP method. Gen. Res. Crop Evol., 50, 489-495.

Patocchi, A., Frei, A., Frey, J. E., Kellerhals, M. (2009). Towards improvement of marker assisted selection of apple scab resistant cultivars: Venturia inaequalis avirulence surveys and standardization of molecular marker alleles associated with resistance genes. Mol. Breed., 24 (4), 337-347.

Pierantoni, L., Dondini, L., Cho, K.-H., Shin, I.-S., Gennari, F., Chiodini, R., Tartarini, S., Kang, S.-J., Sansavini, S. (2007). Pear scab resistance QTLs via a European pear (Pyrus communis) linkage map. Tree Genetics Genomes, 3, 311-317.

Postman, J. D., Spotts, R. A., Calabro, J. (2005). Scab resistance in Pyrus Germplasm. Acta Hort., 671, 601-608.

Potts, S. M., Han, Y., Khan, M. A., Kushad, M. M., Rayburn, A. L., Korban, S. S. (2012). Genetic diversity and characterization of a core collection of malus germplasm using simple sequence repeats (SSRs). Plant Mol. Biol. Rep., 30, 827-837.

Rashal, I., Lacis, G. (1999). Accessions of horticultural plants in the Latvian plant genetic resources data base. In: Fruit Growing Today and Tomorrow. Collection of Scientific Articles, 4 September, 1998 (pp. 124-130). Dobele, Latvia.

Rashal, I., Rashal D. (1996). Horticulture accessions in the Latvian plant genetic resources database. In: Problems of Fruit Plant Breeding. Collection of Scientific Articles (pp. 38-41). LLU, Jelgava, Latvia.

Ruisa, S., Lacis, G. (2001). Characterization of Chaenomeles japonica genetic resources. Hort. Veget. Grow., 20 (3), 50-60.

Schuster, M. (2012). Incompatible (S-) genotypes of sweet cherry cultivars (Prunus avium L.). Sci. Hort., 148, 59-73.

Sefc, K. M., Lefort, F., Grando, M. S., Scott, K. D., Steinkellner, H., Thomas, M. R. (2001). Microsatellite markers for grapevine: A state of the art. In: Roubelakis-Angelakis, K. A. (ed.). Mol. Biol. Biotechnol. Grapevine (pp. 1-30). Dordrecht,: Kluwer Academic Publishers.

Sehic, J., Garkava-Gustavsson, L., Fernández-Fernández, F., Nybom, H (2012). Genetic diversity in a collection of European pear (Pyrus communis) cultivars determined with SSR markers chosen by ECPGR. Sci. Hort., 145, 39-45

Sikorskaite, S., Gelvonauskiene, D., Stanys, V., Baniulis D. (2012). Characterization of microsatellite loci in apple (Malus $\times$ domestica Borkh.) cultivars. Žemdirbystè (Agriculture), 99 (2), 131-138. 
Sonneveld, T., Tobutt, K. R., Robbins, T. P. (2003). Allele-specific PCR detection of sweet cherry self-incompatibility $(S)$ alleles $S 1$ to $S 16$ using consensus and allele specific primers. Theor. Appl. Genet., 107, 1059-1070.

Spooner, D., van Treuren, R., de Vicente, M.C. (eds.). (2005). Molecular Markers for Genebank Management. IPGRI Technical Bulletin No. 10. Rome: International Plant Genetic Resources Institute. 126 pp.

Stanys, V., Baniulis, D., Morkunaite-Haimi, S., Siksnianiene, J. B., Frercks, B., Gelvonauskiene, D., Stepulaitiene, I., Staniene, G., Siksnianas, T. (2012). Characterising the genetic diversity of Lithuanian sweet cherry (Prunus avium L.) cultivars using SSR markers. Sci. Hort., 142, 136-142.

Storti, A., Via, J. D., Baric S. (2012). Comparative molecular genetic analysis of apple genotypes maintained in germplasm collections. ErwerbsObstbau, 55 (3), 137-141.

Strautina, S., Kampuss, K. (2002). Research of Latvian Ribes Genetic Resources. Acta Hort., 585, 171-176.

Received 22 January 2013
Tao, R., Iezzoni, A. F. (2010). The S-RNase-based gametophytic self-incompatibility system in Prunus exhibits distinct genetic and molecular features. Sci. Hort., 124 (4), 423-433.

Trajkovski, V., Hjalmarsson, I. (2007). The value of national fruit gene banks. Žemès Ūkio Mokslai (Agricultural Sciences), 14 (4), 28-32.

van Treuren, R., Kemp, H., Ernsting, G., Jongejans, B., Houtman, H., Visser, L. (2010). Microsatellite genotyping of apple (Malus domestica Borkh.) genetic resources in the Netherlands: Application in collection management and variety identification. Gen. Res. Crop Evol., 57 (6), 853-865.

Wang, A., Zhang, Q., Wan, D., Yang, Y., Liu, J. (2008). Nine microsatellite DNA primers for Hippophae rhamnoides ssp. sinesis (Elaeagnaceae). Conserv. Genet., 9, 969-971.

Weising, K., Nybom, H., Wolff, K., Kahl, G. (eds.). (2005). DNA Fingerprinting in Plants: Principles, Methods, and Applications. Boca Raton: CRC Press, Taylor \& Francis Group. 444 pp.

Yamamoto, T., Kimura, T., Sawamura, Y., Manabe, T., Kotobuki, K., Hayashi, T., Ban, Y., Matsuta, N. (2002). Simple sequence repeats for genetic analysis in pear. Euphytica, 124, 129-137.

\section{LATVIJAS AUGL,AUGU ĢENĒTISKO RESURSU RAKSTUROŠANA PIELIETOJOT MOLEKULĀRĀS ĢENĒTIKAS METODES}

Latvijas Valsts aug̣̣kopības institūta (LVAI) kolekcijā tiek saglabāts daudzveidīgs augḷaugu augu materiāls, ko veido mūsdienu un tautas selekcijas šḳirnes, institūtā radītais selekcijas materiāls, kā arī citās valstīs izveidotās škiirnes, kas iegūtas ilgstošas apmaiṇas un sadarbības rezultātā ar citiem zinātniskiem institūtiem. Pašlaik kolekcijā ietverti 2509 paraugi, kas pārstāv 17 augḷaugu kultūras. 676 paraugi ir definēti kā valsts nozīmes ǵenētiskie resursi. Auglạgu ǵenētisko resursu kolekciju vērtību nosaka to tālāka izmantošana, kas nav iespējama bez augu materiāla detalizētas raksturošanas un novērtēšanas. Sevišḳi nozīmīga daudzgadīgo kultūraugu raksturošanā ir molekulāro markieru tehnoloğiju ieviešana un pielietošana. Iespējams izdalīt divas galvenās pielietoto molekulāro marḳieru grupas: nespecifiskie markiieri un gēnu specifiskie marķieri, kas vēlāk pielietojami uz marḳieriem balstîtajā atlasē. Pielietojot SSR, RAPD un MSAP markiierus LVAI kolekcijā veikta genotipēšana divpadsmit aug̣̣augu kultūrām, raksturojot 790 genotipus. Iegūtā informācija izmantota augu materiāla identifikācijai, nosaukuma atbilstības pārbaudei, kā arī ğenētiskās daudzveidības un kolekcijas iekšējās struktūras novērtēšanai. Markieru metožu ieviešana veikta saskaņā ar ECPGR darba grupu ieteikumiem, lai nodrošinātu starptautisko datu apmaiņu. Gēnu specifiskie molekulārie markieru lietoti, raksturojot ābeles un bumbieres (izturība pret kraupi), zemenes (izturība pret Gnomonia fragariae), saldos kiršus un plūmes (pašnesaderība). 